\title{
Studi Eksploratif Tentang Pemahaman Guru Terhadap Kerangka Kerja TPACK Dalam Pembelajaran Matematika di Tengah Pandemi di SMA Kota Jambi
}

\author{
Munajib $^{1}$, Sutrisno ${ }^{2}$, Kamid $^{3}$ \\ 1, 2, 3 Program Studi Magister Pendidikan Matematika, Fakultas Ilmu Pendidikan, Universitas Jambi, \\ Jl Raya Jambi - Muara Bulian KM.15 Mendalo Indah, Muaro Jambi, Jambi, Indonesia \\ najibarfa@gmail.com
}

\begin{abstract}
The COVID-19 pandemic seems to "force" teachers and students to modernize learning. In modern times like now, humans are very dependent on technology, especially during a pandemic. All levels of schools in Jambi City are conducting online learning (online). No exception in the mathematics learning process at the high school level. Based on the background of the problems that have been described, the formulation of the problem of this research is how is the teacher's understanding of the TPACK framework in learning mathematics during the COVID-19 pandemic in Jambi City High School? And the goal is to describe how teachers understand the TPACK framework in learning mathematics during the COVID-19 pandemic in Jambi City High Schools. In terms of problems in this study, this research approach uses a qualitative approach. Based on the results of research and discussion, it was concluded that the understanding of mathematics teachers at SMA Kota Jambi towards the TPACK framework in online mathematics learning during the COVID-19 pandemic was quite good.
\end{abstract}

Keywords: Tecnological, Pedagogical, Content Knowledge, TPACK, mathematics

\begin{abstract}
Abstrak
Pandemi COVID-19 seakan "memaksa" guru dan siswa untuk melakukan modernisasi dalam pembelajaran. Di zaman modernisasi seperti sekarang, manusia sangat bergantung pada teknologi, terlebih di saat pandemi. Semua tingkat sekolah di Kota Jambi yang melakukan pembelajaran secara daring (online). Tak terkecuali dalam proses pembelajaran matematika di tingkat SMA. Berdasarkan latar belakang masalah yang telah diuraikan, maka rumusan masalah penelitian ini adalah bagaimana pemahaman guru terhadap kerangka kerja TPACK yang merupakan salah satu framework yang mengintegrasikan antara pengetahuan teknologi (Technologial Knowledge), pengetahuan pedagogi (Pedagogy Knowledge), dan pengetahuan konten (Content Knowledge) dalam pembelajaran matematika selama pandemi COVID-19 di SMA Kota Jambi? Dan tujuan yang ingin dicapai adalah mendeskripsikan bagaimana pemahaman guru terhadap kerangka kerja TPACK dalam pembelajaran matematika selama pandemi COVID-19 di SMA Kota Jambi. Berangkat dari fokus permasalahan dalam penelitian ini, maka pendekatan penelitian ini menggunakan pendekatan kualitatif. Berdasarkan hasil penelitian dan pembahasan diperoleh kesimpulan bahwa pemahaman guru-guru matematika di SMA Kota Jambi terhadap kerangka kerja TPACK dalam pembelajaran matematika secara daring selama pandemi COVID-19 cukup baik.
\end{abstract}

Kata kunci: Teknologi, Pedagogika, Pengetahuan konten, TPACK, matematika

Copyright (c) 2021 Munajib, Sutrisno, Kamid

$\square$ Corresponding author: Munajib

Email Address: najibarfa@ gmail.com (Jl. Raya Jambi - Muara Bulian KM.15 Jambi, Indonesia)

Received 22 Desember 2020, Accepted 20 Februari 2021, Published 11 Maret 2021

\section{PENDAHULUAN}

Pandemi COVID-19 seakan "memaksa" guru dan siswa untuk melakukan modernisasi dalam pembelajaran. Modernisasi adalah bentuk dari keadaan yang kurang maju atau kurang berkembang ke arah yang lebih baik dengan harapan akan tercapai kehidupan masyarakat yang lebih maju, berkembang, dan makmur yang merupakan hasil kemajuan ilmu pengetahuan yang terus berkembang sekarang ini. Di zaman modernisasi seperti sekarang, manusia sangat bergantung pada teknologi, terlebih di saat pandemi. Sujadi (Sujadi 2018) menjelaskan era revoluasi 4.0, menjadi perubahan yang besar terutama bidang kehidupan pada teknologi modern, tak terkecuali perubahan yang terjadi pada bidang pendidikan. Memasuki revolusi industry 4.0 dunia pendidikan dituntut untuk mengkonstruksi 
pembelajaran yang melibatkan teknologi(Sintawati and Indriani 2019). Hal ini membuat teknologi menjadi kebutuhan dasar setiap orang. Karena melalui teknologi, manusia dapat mengurangi interaksi sesama manusia yang bisa mencegah penyebaran COVID-19. Proses pembelajaran dilaksanakan dalam masa covid 19 hanya dapat mengukur dua aspek yaitu kognitif dan psikomotorik (Amaludin et al. 2021).

Berdasarkan permasalah tersebut maka proses pembelajaran di sekolah-sekolah termasuk perguruan tinggi dilakukan secara daring (online) dengan menggunakan berbagai platform. Semua tingkat sekolah di Kota Jambi yang melakukan pembelajaran secara daring (online). Tak terkecuali dalam proses pembelajaran matematika di tingkat SMA. Berdasarkan hasil observasi dan wawancara penulis terhadap salah satu guru matematika di salah satu SMA Negeri di Kota Jambi yang bernama YP beliau mengatakan "untuk tetap bisa mencapai target kurikulum, maka pembelajaran matematika di kelas yang saya ampuh segera dilaksanakan secara online karena kita tidak tau sampai kapan pandemi ini akan berakhir".

Hal senada juga dikatakan oleh guru matematika yang lainnya yang berasal dari SMA swasta di Kota Jambi bernama AS yang mengatakan "siap tidak siap, pembelajaran harus tetap berjalan, mau tidak mau secara daring (online)". Menurut (Permatasari, Maziyah, and Fadila 2021) berpendapat pembelajaran daring (online) menimbulkan permasalahan dalam proses pembelajaran, seperti jaringan yang buruk, penyampaiyan materi yang kurang optimal dan banyak tugas rumah yang diberikan kepada peserta didik. Sejalan dengan permasalaan tersebut, (Yohafrinal, Damris 2015) berpendapat bahwa guru harus dapat menguasai empat dimensi berupa pengetahuan tentang strategi pembelajara, materi pembelajaran, pembelajaran yang mendidik dan keterampilan komunikasi dengan peserta didik dengan melakukan evaluasi.

Berdasarkan permasalahan di atas, penulis merasa tertarik untuk melakukan ekplorasi secara mendalam untuk mengetahui tentang pemahaman guru matematika terhadap kerangka kerja TPACK yang merupakan intergasi antara pengetahuan teknologi, pengetahuan pedagogi, dan pengetahuan konten (Technological Pedagogical Content Knowledge)(Sabrina 2019; Sintawati and Indriani 2019) dalam pelaksanaan pembelajaran daring selama pandemi COVID-19 di SMA Kota Jambi. Adapun teknologi yang digunakan adalah teknologi ICT dalam pembelajaran daring. Menurut (Rosyid 2016) berpendapat bahwa kehadiran teknologi dan perkembangan ilmu pengetahuan dapat menjadi salah satu batu loncatan dalam meningkatkan kualitas pembelajaran peserta didik yang dilakukan oleh gurumaka dari itu guru mampu memahami dan memiliki kemampuan TPACK atau Technological Pedagogical Content Knowledge.

\section{METODE}

\section{Tempat dan Waktu Penelitian}

Penelitian ini dilaksanakan di SMA yang berada Kota Jambi yang berstatus negeri maupun swasta, serta melalui beberapa tahapan, yaitu tahap persiapan, tahap pelaksanaan, tahap analisa data, dan 
penyusunan laporan. Penelitian dimulai dengan tahap persiapan pada bulan April 2020, pengambilan data pada bulan November sampai penyusunan laporan pada bulan November dan Desember 2020. Instrumen dalam penelitian ini berupa angket, observasi dan wawancara. Adapun subjek dalam penelitian ini adalah seluruh guru-guru matematika SMA Kota Jambi yang mengajar materi statistika, sehingga teknik sampling yang digunakan adalah purposive sampling. Berikut digram air tahapan penelitian:

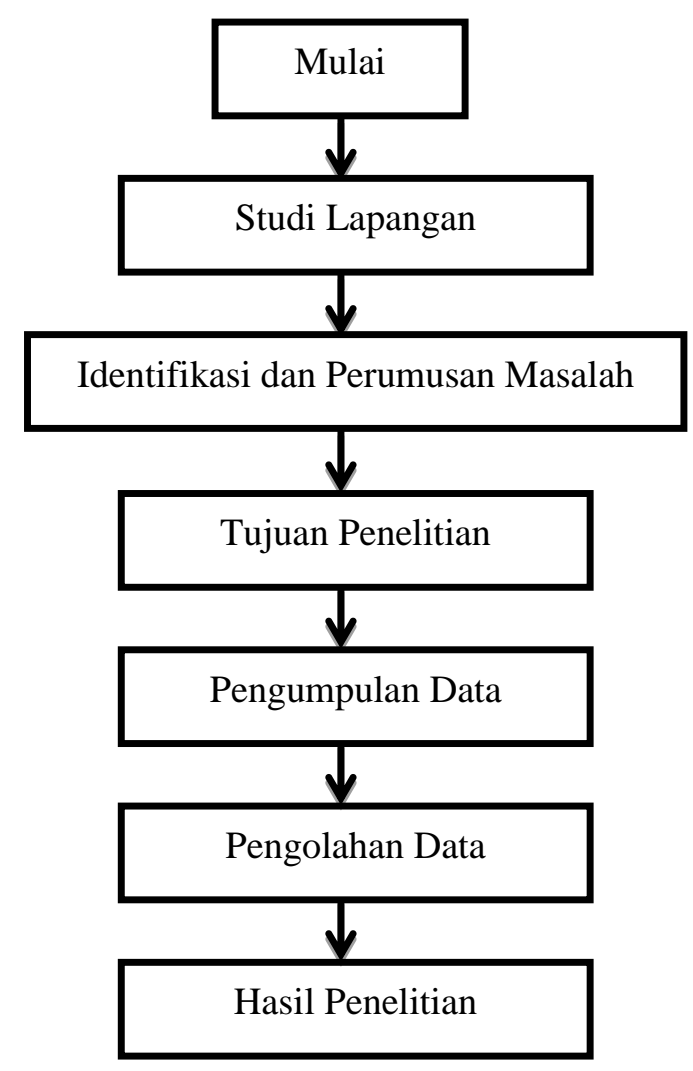

Gambar 1. Bagan Alir Penelitian

\section{Pendekatan Penelitian}

Berangkat dari fokus permasalahan dalam penelitian ini, maka pendekatan penelitian ini menggunakan pendekatan kualitatif. Menurut (Moleong 2006:6) , penelitian kualitatif adalah penelitian yang bermaksud untuk memahami fenomena apa yang dialami oleh subjek penelitian misalnya perilaku, persepsi, motivasi, tindakan, dan lain lain, secara holistik, dan dengan cara deskripsi dalam bentuk kata-kata dan bahasa, pada suatu konteks khusus yang alamiah dan dengan memanfaatkan berbagai metode alamiah. Sedangkan menurut (Conny R. Semiawan 2010:1) pendekatan kualitatif memiliki tujuan untuk mencari pengertian secara mendalam tentang suatu gejala, fakta atau realita serta peristiwa/fenomena yang dapat dipahami penelit, tidak hanya terbatas pada permukaannya saja. Penelitian kualitatis tidak diperoleh melalui prosedur statistic atau menggunakan metode kuantifikasi yang lain (Albi Anggito dan Johan Setiawan 2018:7).

Menurut (Anselm Straus dan Juliet Corbin 2013:4) penelitian kualitatif adalah penelitian yang temuan-temuannya tidak diperoleh melalui prosedur statistik atau bentuk hitungan. Ditinjau dari jenis 
penelitiannya, penelitian ini termasuk penelitian lapangan (field research), karena penelitian ini mempelajari secara intensif tentang latar belakang keadaan sekarang dan interaksi lingkungan suatu unit sosial, kelompok, lembaga dan masyarakat yang dilaksanakan dalam kehidupan dan realitas yang sebenarnya.

Menurut (Sutrisno 2011) menjelaskan bahwa yang memperkenalkan TPCK bertujuan sebagai kerangka kerja guru atau pengajar dalam mengintegrasi pembelajaran. Pendekatan kualitatif dipilih dalam penelitian ini karena beberapa pertimbangan antara lain: (1) Penelitian ini merupakan upaya untuk mendeskripsikan pemahaman guru dan permasalahannya terhadap kerangka kerja TPACK dalam pembelajaran matematika selama pandemi COVID-19 di SMA Kota Jambi; (2) Penelitian ini lebih bersifat induktif, artinya peneliti berusaha mendeskripsikan permasalahan berdasar data yang terbuka bagi penelitian lebih lanjut; (3) Penelitian ini dilakukan dalam situasi pandemi COVID-19 sehingga penelitian mengutamakan data yang bersifat kualitatif.

\section{HASIL DAN DISKUSI}

\section{Data Subjek Penelitian}

Berikut data subjek peneltian atau responden yang diperoleh dari penelitian

Tabel 1 Data Responden Penelitian

\begin{tabular}{|c|c|l|c|}
\hline No & Nama & \multicolumn{1}{|c|}{ Tempat Mengajar } & Pendidikan \\
\hline 1 & AR & SMAN 3 Kota Jambi & S2 \\
\hline 2 & YP & SMAN 1 Kota Jambi & S1 \\
\hline 3 & AS & SMAN 13 Kota Jambi & S1 \\
\hline 4 & IF & SMAN 12 Kota Jambi & S2 \\
\hline 5 & AS & SMAS Xaverius Jambi & S1 \\
\hline 6 & CL & SMAN 6 Kota Jambi & S1 \\
\hline 7 & EA & SMAN 5 Kota Jambi & S1 \\
\hline 8 & LK & SMAN 8 Kota Jambi & S2 \\
\hline 9 & MN & SMAS Adhiyaksa 1 Kota Jambi & S1 \\
\hline 10 & AL & SMAS DB 4 Kota Jambi & S1 \\
\hline 11 & ST & SMAS Islam Al-Falah Kota Jambi & S1 \\
\hline 12 & AC & SMAS Ferdy Fery Putra & S1 \\
\hline 13 & BJ & SMAS Adhiyaksa 1 Kota Jambi & S1 \\
\hline 14 & SM & SMAN 7 Kota Jambi & S1 \\
\hline 15 & MG & SMAN 3 Kota Jambi & S1 \\
\hline 16 & RR & SMAS Nomensen Kota Jambi & S1 \\
\hline 17 & RH & SMAN 3 Kota Jambi & SMAN 10 Kota Jambi \\
\hline 18 & NE & SMA & \\
\hline 19 & LP & SMA Kristen Bina Kasih & \\
\hline
\end{tabular}

\section{Pemahaman Pedagogy Knowledge (PK)}

Menurut (Koehler et al. 2014) Pedagogical Knowledge adalah pengetahuan guru terhadap pelaksanaan, strategi dan metode dalam mendukung pembelajaran Adapun hasil temuan penelitian dari pemahaman guru terhadap kerangka kerja pedagogy knowledge sebagai berikut: 
Tabel 2. Instrumen Kerangka Kerja PK

\begin{tabular}{|l|l|c|c|}
\hline No & Instrumen Kerangka Kerja PK & $\begin{array}{c}\text { Persentase Kemampuan } \\
\text { Guru }\end{array}$ & Kategori \\
\hline 1 & $\begin{array}{l}\text { Mampu memilih strategi khusus } \\
\text { yang sesuai untuk mengajarkan } \\
\text { statistika secara daring di era } \\
\text { pandemi COVID-19 }\end{array}$ & $94 \%$ & Sangat Baik \\
\hline 2 & $\begin{array}{l}\text { Mampu menggunakan berbagai } \\
\text { strategi yang berhubungan dengan } \\
\text { konsep dalam materi } \\
\text { pembelajaran statistika secara } \\
\text { daring di era pandemi COVID-19 }\end{array}$ & $84 \%$ & Cukup \\
\hline 3 & $\begin{array}{l}\text { Mampu menggunakan metodologi } \\
\text { pembelajaran materi statistika } \\
\text { sesuai dengan karakteristik siswa } \\
\text { serta umpan baliknya }\end{array}$ & $63 \%$ & \\
\hline
\end{tabular}

Kategori diadaptasi dari kriteria interpretasi skor (arikunto 2011):

$\begin{array}{ll}84 \%-100 \% & : \text { Sangat Baik } \\ 68 \%-83 \% & : \text { Baik } \\ 52 \%-67 \% & : \text { Cukup } \\ 36 \%-51 \% & : \text { Kurang Baik } \\ <35 \% & : \text { Tidak Baik }\end{array}$

Berdasarkan hasil penelitian di lapangan terhadap pemahaman pedagogy knowledge guru matematika di SMA yang berada di kawasan Kota Jambi, didapat sebanyak 18 guru mampu memilih strategi khusus yang sesuai untuk mengajarkan materi statistika secara daring di era pandemi covid 19. Sementara 1 guru tidak mampu memilih strategi khusus dikarenakan guru tersebut merasa memiliki keterbatasan dalam pembelajaran daring terutama dari segi memilih strategi daring yang tepat.

Sebanyak 16 guru mampu menggunakan berbagai strategi yang berhubungan dengan konsep dalam materi pembelajaran statistika secara daring di era pandemi COVID-19, namun masih ada 3 orang guru yang tidak mampu menggunakan berbagai strategi yang berhubungan dengan konsep dalam materi pembelajaran statistika secara daring di era pandemi COVID-19, dikarenakan guru tidak dapat mendeteksi strategi yang pas dengan kondisi pembelajaran daring. Hal ini dikarenakan sebagian besar siswa tidak menunjukkan umpan balik seperti dalam pembelajaran langsung di kelas, sehingga guru hanya menggunakan satu strategi saja dalam pembelajaran. Sebanyak 12 guru mampu menggunakan metodologi pembelajaran materi statistika sesuai dengan karakteristik siswa serta umpan baliknya, namun ada sebanyak 7 orang guru tidak mampu menggunakan metodologi pembelajaran materi statistika sesuai dengan karakteristik siswa serta umpan baliknya. Hal ini dikarenakan guru tidak melihat karakteristik siswa yang beragam, materi yang diberikan melalui video pembelajaran adalah untuk semua siswa tanpa memandang karalteristik siswa, berbeda ketika 
dengan pembelajaran langsung dimana karakteristik siswa bisa terlihat. Selain itu juga sebagian guru terkendala dengan komunikasi dua arah yang harusnya terjadi dalam pembelajaran, hal ini terjadi dikarenakan sebagian siswa kurang aktif dan kurang peduli terhadap pembelajaran.

\section{Pemahaman Technology Knowledge (TK)}

Tabel 3 Instrumen Kerangka Kerja TK

\begin{tabular}{|c|l|c|c|}
\hline No & \multicolumn{1}{|c|}{ Instrumen Kerangka Kerja TK } & $\begin{array}{c}\text { Persentase Kemampuan } \\
\text { Guru }\end{array}$ & Kategori \\
\hline 1 & $\begin{array}{l}\text { Mampu mengatasi permasalahan } \\
\text { terkait dengan software dan koneksi }\end{array}$ & $58 \%$ & Cukup \\
\hline 2 & $\begin{array}{l}\text { Mampu mengikuti berbagai } \\
\text { perkembangan software, mendowload } \\
\text { dan menginstal program }\end{array}$ & $84 \%$ & Cukup \\
\hline 3 & $\begin{array}{l}\text { Mampu membantu siswa dalam hal } \\
\text { persoalan teknis berkenaan dengan } \\
\text { persoalan komputer }\end{array}$ & $63 \%$ & \\
\hline
\end{tabular}

Berdasarkan hasil penelitian di lapangan terhadap pemahaman technology knowledge guru matematika di SMA yang berada di kawasan Kota Jambi, didapat sebanyak 11 guru mampu mengatasi permasalahan terkait dengan software dan koneksi. Sebanyak 8 guru tidak mampu mengatasi permasalahan terkait dengan software dan koneksi dikarenakan sebagian guru tidak menguasai teknologi dalam pembelajaran daring secara menyeluruh, seperti ketika terjadi gangguan dari sisi software baik yang dihadapi guru maupun siswa. Guru hanya sebatas mampu mengoperasikan software namun tidak mampu mengatasi gangguan yang terjadi terkait teknologi yang digunakan.

Sebanyak 16 orang guru sudah mampu mengikuti berbagai perkembangan software, mendowload dan menginstal program namun masih ada 3 orang guru yang masih belum mampu mengikuti berbagai perkembangan software, mendowload dan menginstal program dikeranakan sudah terbiasa dibantu oleh operator sekolah dan sebagian guru memiliki permasalahan dari keterbatasan memory dari perangkat ponsel yang digunakan. Sebanyak 12 orang guru sudah mampu membantu siswa dalam hal persoalan teknis berkenaan dengan persoalan komputer. Namun masih ada 7 orang guru yang kurang mampu membantu siswa dalam hal persoalan teknis berkenaan dengan persoalan komputer dikarenakan guru-guru terutama yang berusia diatas 40 tahun banyak yang tidak memahami teknis komputer secara baik.

\section{Pemahaman Content Knowledge (CK)}

Pedagogical Content Knowledge sebagai pengukur dalam mengetahui pendekatan pengajaran yang sesuai dengan elemen konten untuk proses pembelajaran yang jauh lebih baik (Malik, Firdaus, and Tidar 2020). 
Tabel 4. Intsrumen Kerangka Kerja CK

\begin{tabular}{|c|l|c|c|}
\hline No & \multicolumn{1}{|c|}{$\begin{array}{c}\text { Instrumen Kerangka Kerja } \\
\text { CK }\end{array}$} & $\begin{array}{c}\text { Persentase Kemampuan } \\
\text { Guru }\end{array}$ & Kategori \\
\hline 1 & $\begin{array}{l}\text { Mampu memetakan materi } \\
\text { statistika sesuai dengan } \\
\text { standar kurikulum }\end{array}$ & $79 \%$ & Sangat Baik \\
\hline 2 & $\begin{array}{l}\text { Mampu menentukan cakupan } \\
\text { konsep-konsep materi } \\
\text { statistika yang diajarkan }\end{array}$ & $100 \%$ & Sangat Baik \\
\hline 3 & $\begin{array}{l}\text { Mampu merencanakan urutan } \\
\text { konsep-konsep dalam materi } \\
\text { statistika }\end{array}$ & $100 \%$ & \\
\hline
\end{tabular}

Berdasarkan hasil penelitian di lapangan terhadap pemahaman Content Knowledge guru matematika di SMA yang berada di kawasan Kota Jambi, didapat sebanyak 15 orang guru sudah mampu memetakan materi statistika sesuai dengan standar kurikulum. Namun masih ada 4 orang guru yang tidak memetakan materi statistika sesuai dengan standar kurikulum, dikarenakan guru tidak mampu mengejar seluruh materi yang ada di dalam kurikulum dikeranakan merasa kesulitan dalam memetakan sesuai kebutuhan kurikulum, jadwal pembelajaran yang diberikan sekolah juga dipersingkat sehingga guru tidak memiliki waktu yang cukup.

Dari penelitian terlihat bahwa semua guru yaitu sebanyak 19 orang guru matematika yang menjadi responden sudah mampu menentukan cakupan konsep-konsep materi statistika yang diajarkan, serta sudah mampu merencanakan urutan konsep-konsep dalam materi statistika.

\section{Pemahaman Technology Content Knowledge (TCK)}

Tabel 5. Instrumen Kerangka Kerja TCK

\begin{tabular}{|c|l|c|c|}
\hline No & $\begin{array}{l}\text { Instrumen Kerangka Kerja } \\
\text { TCK }\end{array}$ & $\begin{array}{c}\text { Persentase Kemampuan } \\
\text { Guru }\end{array}$ & Kategori \\
\hline 1 & $\begin{array}{l}\text { Mampu menggunakan teknologi } \\
\text { video untuk mendemonstrasikan } \\
\text { konsep-konsep khusus sesuai } \\
\text { dengan materi statistika }\end{array}$ & $100 \%$ & Sangat Baik \\
\hline 2 & $\begin{array}{l}\text { Mampu mengimplementasikan ke } \\
\text { dalam kurikulum sesuai dengan } \\
\text { materi statistika yang diajarkan }\end{array}$ & $84 \%$ & Baik \\
\hline 3 & $\begin{array}{l}\text { Mampu menggunakan berbagai } \\
\text { alat bantu untuk menyampaikan } \\
\text { materi statistika secara daring }\end{array}$ & $79 \%$ & \\
\hline
\end{tabular}

Berdasarkan hasil penelitian di lapangan terhadap pemahaman Content Knowledge guru matematika di SMA yang berada di kawasan Kota Jambi, didapat sebanyak 19 guru. Artinya semua guru yang menjadi responden penelitian mampu menggunakan teknologi video untuk mendemonstrasikan konsep-konsep khusus sesuai dengan materi statistika. 
Sebanyak 16 orang guru mampu mengimplementasikan ke dalam kurikulum sesuai dengan materi statistika yang diajarkan namun masih ada 3 guru belum mampu mengimplementasikan ke dalam kurikulum sesuai dengan materi statistika yang diajarkan. Hal ini dikarenakan guru merasa banyak keterbatasan dalam pembelajaran daring sehingga implementasi kurikulum tidak bisa diimplementasikan secara maksimal.

Sebanyak 15 orang guru mampu menggunakan berbagai alat bantu untuk menyampaikan materi statistika secara daring, namun masih ada 4 orang guru tidak mampu menggunakan berbagai alat bantu untuk menyampaikan materi statistika secara daring. Hal ini dikeranakan sebagian guru tidak memiliki banyak pilihan alat dalam pembelajaran daring, sehingga alat yang digunakan hanya sebatas yang dimiliki guru saja yang biasanya hanya ada 1 atau 2 alat penunjang pembelajaran seperti hp dan laptop.

\section{Pemahaman Pedagogy Content Knowledge (PCK)}

Tabel 6 Instrumen Kerangka Kerja PCK

\begin{tabular}{|l|l|c|c|}
\hline No & \multicolumn{1}{|c|}{$\begin{array}{l}\text { Instrumen Kerangka Kerja } \\
\text { PCK }\end{array}$} & $\begin{array}{c}\text { Persentase Kemampuan } \\
\text { Guru }\end{array}$ & Kategori \\
\hline 1 & $\begin{array}{l}\text { Mampu membedakan yang } \\
\text { benar dan salah tentang } \\
\text { persoalan materi statistika yang } \\
\text { dihadapi siswa }\end{array}$ & $95 \%$ & Sangat Baik \\
\hline 2 & $\begin{array}{l}\text { Mampu mengantisipasi } \\
\text { kesalahan konsep pada materi } \\
\text { statistika yang diajarkan }\end{array}$ & $84 \%$ & Sangat Baik \\
\hline 3 & $\begin{array}{l}\text { Mampu menyusun rancangan } \\
\text { pembelajaran yang sesuai } \\
\text { dengan materi pembelajaran }\end{array}$ & $100 \%$ & Sangat Baik \\
\hline 4 & $\begin{array}{l}\text { Mampu membantu siswa dalam } \\
\text { hubungan antar konsep materi } \\
\text { statistika yang diajarkan }\end{array}$ & $95 \%$ & \\
\hline
\end{tabular}

Pemahaman Pedagogy Content Knowledge guru matematika di SMA yang berada di kawasan Kota Jambi, didapat sebanyak 18 guru sudah mampu membedakan yang benar dan salah tentang persoalan materi statistika yang dihadapi siswa. Namun masih ada 1 orang guru yang kurang mampu membedakan yang benar dan salah tentang persoalan materi statistika yang dihadapi siswa dikerankan sebagian siswa yang tertutup terhadap pembelajaran sehingga tidak ada umpan balik dari siswa yang terjadi adalah guru tidak mampu mendeteksi siswa paham atau tidak.

Sebanyak 16 orang guru mampu mengantisipasi kesalahan konsep pada materi statistika yang diajarkan, namun masih ada 3 orang guru yang kurang mengantisipasi kesalahan konsep pada materi statistika yang diajarkan. Hal ini dikarenakan guru merasa siswa tidak menunjukkan respon yang baik dalam pembelajaran daring sehingga guru tidak bisa melihat proses penalaran siswa dalam pembelajaran daring, sehingga kemungkinan dari kesalahan konsep pada siswa sulit dideteksi oleh guru. Namun semua guru yang menjadi responden sudah mampu menyusun rancangan pembelajaran 
yang sesuai dengan materi pembelajaran. Sebanyak 18 orang guru mampu membantu siswa dalam hubungan antar konsep materi statistika yang diajarkan, namun masih ada 1 orang guru yang kurang mampu membantu siswa dalam hubungan antar konsep materi statistika yang diajarkan. Hal ini dikeranakan karakteristik siswa yang berbeda-beda ditambah dengan kondisi pembelajaran jarak jauh terkadang terjadi masalah jaringan yang menyebabkan hal tersebut sulit untuk dilakukan secara maksimal.

\section{Pemahaman Technology Pedagogical Knowledge (TPK)}

Tabel 7. Instrumen Kerangka Kera TPK

\begin{tabular}{|c|c|c|c|}
\hline No & $\begin{array}{c}\text { Instrumen Kerangka Kerja } \\
\text { TPK }\end{array}$ & $\begin{array}{c}\text { Persentase Kemampuan } \\
\text { Guru }\end{array}$ & Kategori \\
\hline 1 & $\begin{array}{l}\text { Mampu membuat pembelajaran } \\
\text { berbasis teknologi untuk } \\
\text { membangun pengetahuan dan } \\
\text { keterampilan siswa }\end{array}$ & $74 \%$ & Baik \\
\hline 2 & $\begin{array}{l}\text { Mampu menerapkan } \\
\text { pembelajaran statistika yang } \\
\text { terpusat pada siswa dengan } \\
\text { menggunakan teknologi }\end{array}$ & $74 \%$ & Baik \\
\hline 3 & $\begin{array}{lr}\text { Mampu menjadi moderator } \\
\text { secara interaktif } & \text { dan } \\
\text { menyenangkan } & \text { pada } \\
\text { pembelajaran statistika } & \text { secara } \\
\text { daring } & \\
\end{array}$ & $95 \%$ & Sangat Baik \\
\hline
\end{tabular}

Pemahaman technology pedagogy knowledge guru matematika di SMA yang berada di kawasan Kota Jambi, didapat 14 guru mampu membuat pembelajaran berbasis teknologi untuk membangun pengetahuan dan keterampilan siswa. Namun masih ada 5 orang guru yang kurang mampu membuat pembelajaran berbasis teknologi untuk membangun pengetahuan dan keterampilan siswa, karena pengetahuan dan keterampilan guru dalam penguasaan teknologi IT dalam pembelajaran masih kurang.

Sebanyak 14 orang guru mampu menerapkan pembelajaran statistika yang terpusat pada siswa dengan menggunakan teknologi, namun masih ada 5 orang guru yang kurang mampu menerapkan pembelajaran statistika yang terpusat pada siswa dengan menggunakan teknologi. Hal ini dikarenakan guru memiliki waktu yang lebih sedikit sehingga tujuan utama guru adalah mengejar materi pembelajaran sehingga pembelajaran lebih terpusat kepada guru bukan terpusat kepada siswa.

Sebanyak 18 orang guru mampu menjadi moderator secara interaktif dan menyenangkan pada pembelajaran statistika secara daring, namun masih ada 1 guru yang merasa belum yakin apakah guru tersebut sudah mampu menjadi moderator secara interaktif dan menyenangkan pada pembelajaran statistika secara daring atau belum dikarenakan umpan balik dari siswa yang sangat minim. 


\section{Pemahaman Technology Pedagogy Content Knowledge (TPACK)}

Technology Pedagogy Content Knowledge atau TPACK menjelaskan setiap bidang pengetahuan yang telah diuraikan sebelumnya dengan berfokus kepada penggunaann teknologi yang dibuat dengan khas sesuai dengan kebutuhan pedagogis dalam proses pembelajaran (Rosyid 2016).

Tabel 8. Instrumen Kerangka Kerja TPACK

\begin{tabular}{|l|l|c|c|}
\hline No & \multicolumn{1}{|c|}{ Instrumen Kerangka Kerja } \\
TPACK & $\begin{array}{c}\text { Persentase Kemampuan } \\
\text { Guru }\end{array}$ & Kategori \\
\hline 1 & $\begin{array}{l}\text { Mampu menggunakan sistem } \\
\text { penilaian berbasis portofolio } \\
\text { secara daring }\end{array}$ & $95 \%$ & Sangat Baik \\
\hline 2 & $\begin{array}{l}\text { Mampu menggunakan teknologi } \\
\text { untuk memprediksi } \\
\text { keterampilan siswa dan } \\
\text { pemahamannya dalam topik } \\
\text { pembelajaran statistika }\end{array}$ & $74 \%$ & Sangat Baik \\
\hline 3 & $\begin{array}{l}\text { Mampu menggunakan teknologi } \\
\text { secara efektif untuk membuat } \\
\text { bahan ajar statistika secara } \\
\text { daring menjadi lebih menarik }\end{array}$ & $84 \%$ & \\
\hline
\end{tabular}

Pemahaman technology pedagogy kontent knowledge guru matematika di SMA yang berada di kawasan Kota Jambi didapat bahwa terdapat 18 orang guru mampu menggunakan sistem penilaian berbasis portofolio secara daring. Namun masih ada 1 orang guru yang kurang mampu menggunakan sistem penilaian berbasis portofolio secara daring, dikarenakan guru tidak memiliki penyimpanan data yang cukup untuk membuat portofolio pembelajaran secara daring.

Sebanyak 14 orang guru mampu menggunakan teknologi untuk memprediksi keterampilan siswa dan pemahamannya dalam topik pembelajaran statistika, namun masih ada 5 orang guru yang kurang mampu menggunakan teknologi untuk memprediksi keterampilan siswa dan pemahamannya dalam topik pembelajaran statistika. Sebanyak 16 orang guru mampu menggunakan teknologi secara efektif untuk membuat bahan ajar statistika secara daring menjadi lebih menarik, namun masih ada 3 orang guru yang kurang memahami penggunaan teknologi secara efektif untuk membuat bahan ajar statistika secara daring menjadi lebih menarik. Hal ini dikeranakan pembelajaran daring memiliki banyak keterbatasan mulai dari kondisi perangkat seluler guru yang belum semuanya memadai, kendala jaringan yang sering terjadi, sampai kepada kemampuan guru yang masih terbatas di bidang teknologi penunjang pembelajaran daring.

\section{KESIMPULAN}

Berdasarkan hasil penelitian dan pembahasan, maka dapat disimpulkan bahwa: 1) Pemahaman guru matematika terhadap kerangka kerja TPACK selama pembelajaran daring di era pandemi COVID-19 di tingkat SMA di Kota Jambi berada pada kategori baik (84\%) .2) Dari setiap kerangka kerja diperoleh tingkat pemahaman paling rendah yaitu 68,3\% pada ranah Technology 
Knowledge (TK) dan tertinggi 93,5\% pada ranah Pedadogy Content Knowledge (PCK). Hal ini dikarenakan sebagian besar guru-guru senior berusia lanjut sehingga sebagian sulit memahami teknologi namun memiliki jam terbang mengajar yang tinggi.

\section{UCAPAN TERIMA KASIH}

Penulis menyampaikan terima kasih dan penghargaan kepada: 1) Bapak Prof. Drs. H. Sutrisno, M.Sc., Ph.D. Selaku Rektor Universitas Jambi serta selaku Dosen Pembimbing I penulisan tesis penulis. 2) Bapak Dr.Kamid, M.Si selaku Wakil Rektor Bidang Akademik serta selaku Dosen Pembimbing II penulisan tesis penulis. 3) Ibu Dr. Nizlel Huda, M.Kes selaku Ketua Prodi Magister Pendidikan Matematika. 4)Orang tua, istri serta teman-teman Magister Pendidikan Matematika Universitas Jambi. khirnya semoga Allah SWT berkenan membalas segala kebaikan dan amal semua pihak yang telah membantu. Semoga tesis ini bermanfaat bagi pengembangan ilmu.

\section{REFERENSI}

Albi Anggito dan Johan Setiawan. 2018. Metode Penelitian Kualitatif. Jawa Barat: CV Jejak.

Amaludin, Roni, Wa Ode, Sari Amalia, Universitas Muhammadiyah Kendari, Jalan K. H. Ahmad, Dahlan No, Kota Kendari, and Sulawesi Tenggara. 2021. "Efektivitas Media Pembelajaran ELumak Berbasis Moodle Dan Tingkat Pendapatan Orang Tua Terhadap Hasil Belajar Statistik Pendidikan Di Masa Pandemi Covid-19.” 05(01):286-301.

Anselm Straus dan Juliet Corbin. 2013. Dasar-Dasar Penelitian Kualitatif. Yogyakarta: Pustaka Pelajar.

Conny R. Semiawan. 2010. Metode Penelitian Kualitatif: Jenis, Karakteristik Dan Keunggulan. Jakarta: Grasindo.

Koehler, Matthew J., Punya Mishra, Kristen Kereluik, Tae Seob Shin, and Charles R. Graham. 2014. "The Technological Pedagogical Content Knowledge Framework." 101-11.

Malik, Moch, Al Firdaus, and Universitas Tidar. 2020. "Technological Pedagogical and Content Knowledge ( TPACK ): T He Students ' Perspective on Writing Class.” 3(2):190-99.

Moleong, Lexy J. 2006. Metodologi Penelitian Kualitatif: Edisi Revisi, Cetakan Ke-22. Bandung: PT Remaja Rosdakarya Offset.

Permatasari, Dian, Khizanaturrohmah Nur Maziyah, and Riza Nur Fadila. 2021. "Pengaruh Kemandirian Belajar Terhadap Mathematical Resilience Mahasiswa Dalam Pembelajaran Daring." 05(01):249-58.

Rosyid, Abdul. 2016. "Technological Pedagogical Content Knowledge: Sebuah Kerangka Pengetahuan Bagi Guru Indonesia Di Era Mea." 446-54.

Sabrina, Ibnu Rafi dan Nurrita. 2019. "Technological Pedagogical Content Knowledge ( TPACK ): Integrasi ICT Dalam Pembelajaran IPA Abad 21." Prosiding Seminar Nasional Pendidikan IPA IX (October 2017):1-14.

Sintawati, Mukti and Fitri Indriani. 2019. "Pentingnya Literasi ICT Guru Di Era Revolusi Industri 4.0.” Jurnal Ilmiah Pendidikan Matematika 1(2):417-22.

Sujadi, Imam. 2018. "Peran Pembelajaran Matematika Pada Penguatan Nilai Karakter Bangsa Di Era 
Revolusi Industri 4.0." Prosiding Silogisme Seminar Nasional Pendidikan Matematika Universitas PGRI Madiun 18:1-13.

Sutrisno. 2011. Pengantar Pembelajaran Inovatif Berbasis Teknologi Informasi Dan Komunikasi. Jakarta: GAUNG PERSADA (GP).

Yohafrinal, Damris, Risnita. 2015. "Analisis Pedagogical Content Knowledge (PCK) Guru MIPA Di SMA Negeri 11 Kota Jambi.” 4(2). 